\title{
The Effects of Intellectual Property on Financial Integration in the European Union and Moldova Republic
}

\section{Emmanuel Obed DADZIE*, Ionela Gabriela MATEI ${ }^{* *}$}

\begin{abstract}
In order to encourage creative work and prevent possible abuses, the field of intellectual property must be well regulated; from a legislative point of view. This present era which is characterized by continuous technological progress is experiencing a boost in relevance of intellectual property; thereby becoming one of the key elements of industries. This has made players of markets to become aware of the need to ensure protection of intellectual property rights. Hence, financial integration is a key element which can be affected by intellectual property and the innovation process involved. This paper analyses the correlation between international financial integration and intellectual property. Also, the analysis focuses on European Union (EU) member countries and Moldova in assessing the effects of intellectual property and international financial integration. Fixed-effect panel estimation and the ordinary least squares model are used in the analysis. The analysis has been conducted over the last two decades to see the differences that intellectual property has had over financial integration over periods of time that have had extremely different economic oscillations. The results of this research provide an update on the analysis effects of intellectual property on international financial integration and it shows a negative relationship between them. Hence, this depicts that when intellectual property is carefully considered by firms and governmental institutions, it can be a major source of revenue for the stakeholders and the economy at large.
\end{abstract}

Keywords: intellectual property, financial integration, development, trademarks, industrial design, patents, financial markets

JEL Code: F02, F36, O34

\footnotetext{
* Emmanuel Obed DADZIE is a researcher at Alexandru Ioan Cuza University of Iasi, Iasi, Romania. Email: emmaobeddadzie@gmail.com

** Ionela Gabriela MATEI is a researcher at Alexandru Ioan Cuza University of Iasi, Iasi, Romania. Email: matei.ionelagabriela@gmail.com 


\section{Introduction}

All holders of intellectual property rights must be aware of how such rights are managed and protected. This is an essential aspect which can make an intellectual property lose its value when care is not taken. Intellectual property refers to creations of the mind; inventions, literary and artistic works and symbols, names and images used in commerce. Intellectual property can be classified into several groups. The protection of intellectual property in this era has been on a rise. The need for the protection of intellectual property is backed by several reasons. First of all, humanity's progress and prosperity depend on its creativity in the technical and cultural fields. Second, the legal protection of new creations encourages investment and leads to other innovations. And lastly, the promotion and protection of intellectual property stimulates economic growth, leading to the creation of new jobs and new branches of activity and to the improvement of the quality of life.

An efficient and equitable intellectual property system is a powerful tool for economic development and social and cultural progress. Therefore, such a system can contribute to establishing a balance between the interests of the innovator and the public interest, guaranteeing an environment conducive to both the process of creativity and that of invention.

For an intellectual property to yield great results, the impact of the intellectual property, both home and abroad needs to be considered. An intellectual property which does not have the capacity to serve both the country effectively and efficiently is bound to yield inadequate results in the international market.

Financial market forms one of the bases which is used to assess the extent to which countries are integrated financially. This will be ideal to assess the extent to which intellectual property affects international financial integration. As such, this research is focused on assessing the extent to which intellectual property affects international financial integration. Since the impact of intellectual property is mainly determined by its importance to the global market, the correlation that exists between international financial integration and intellectual property is assessed. Developed countries have capitalized on acquiring more intellectual properties. This serves as a motivation for this research to analyze whether capitalizing on intellectual property (which in this 
research consists of trademarks, patents and industrial design) can boost international financial and development in EU countries including Moldova.

\section{Literature review}

Goldstein and Reese (2008) believe that the main purpose of intellectual property is to encourage the creation of products based on uniqueness or novelty. That said, intellectual property offers consumers temporary access to the information needed for such a creation. The holders of the intellectual property hereby obtain economic incentives. Owners of intellectual property have exclusive rights. This leads to financial stimulation in investing in such products, the only difference being the patents, due to the fact that patents involved the costs associated with research and development in the field (Schroeder \& Singer, 2009). Gancia and Bonfiglioli (2008) argues that the relationship between intellectual property and human rights is a complex one, although there are many moral arguments that complement this claim. Their research also clarifies the fact that intellectual property is a measure that will always be explored due to its nature and characteristics. The research of Mossinghoff (1984) also further discusses on the on the importance and the potential of intellectual property.

\subsection{Types of intellectual property - an overview}

New technologies have created changes in terms of intellectual property by respecting national and international norms and legislation, but also by supporting the creators of knowledge creation (González-González, López, \& Barreto, 2017).

Intellectual property is one of the current concerns of WIPO, due to its characteristics and the role that this phenomenon has both nationally and internationally (de Menezes \& de Santana Falcão, 2020). An intellectual property is bound to be protected for a long period of time, both during the owner's existence and also after his or her death. This policy is applicable to both individuals and groups that own an intellectual property. The United Kingdom Public General Acts, 1988 elaborated on the policies and procedures on intellectual property including the right of attribution and integrity. 
In order to protect and validate a patent (its lifespan may vary up to 20 years or more depending on the legislative jurisdictions of that country or union, etc.) regardless of its destination, it can be registered either nationally or at the international level, which comes along with the payment of fees and sometimes, its translation into a certain language (WIPO, 2013).

In the research of Jones and Smith (1991), they discuss that trademark differ from other types of intellectual property by the characteristics and by the duration of protection they may have. This period may vary due to the possibility of renewal. In this regard, trademarks offer exclusive rights and strengthen the image of products and services which can be registered as the vast majority of intellectual property rights.

Trade secret according to Lin (2013) is a more sensitive type of property being exposed in certain situations by those dishonest behaviors that can endanger the business or the information that makes up that secret. Therefore, those who have hidden information can protect themselves through various more drastic measures, based on medium- and long-term strategies.

Other researchers consider design protection, internet domains, database protection and geographical map as intellectual property. The research and report of Trinder (1992) and EU (2005) shows that industrial designs as intellectual property rights have particularities and limited protection, which may or may not benefit the owner by the options the owner chooses (thus, registration for a limited period of time or non-registration). Internet domains do not offer any special protection as do other intellectual property rights. Therefore, non-registration or incorrect registration may bring with it problems that may be related to other intellectual property rights or by infringing those rights. The protection of databases is based on the content and structure under which they are presented. That said, the rights under which they operate are given by law and copyright. Also, the geographical indications are protected in order to respect the norms of quality and origin of some products. Thus, their protection lies in preventing the inappropriate use or imitation of the name with which they are registered, but also of the characteristics attributed to them.

In order to guarantee intellectual property rights (Emhart, 2019), there is a European Directive 2004/48/CE at European Union level which requires member states to take care of or prevent the occurrence of illegal intellectual 
property, but also to ascertain and take the necessary measures at the time which they take place.

\subsection{Intellectual property - the effects on financial integration}

Intellectual property rights reward creativity and human effort, that is, the engine of human progress. However, there are also demerits of intellectual property viewed from the perspective of financial integration. Such demerits of intellectual property are elaborated below.

- Having identical products or having the same characteristics.

- Creating a logo almost identical to the original, influencing the consumer to believe that he is buying the same product with the same quality as the original or even changing the consumer's perception by believing that the copied product is original.

- Making a patented product with similar specifications or the same as those specified in the original patent without the consent or license of the rightful patent owner.

- Making copies of various creations (musical, artistic, etc.) in order to benefit from large profits without the consent of the rightful owner.

An integrated market has also contributed to the above merits of intellectual property. This where individuals, firms and economies that deem it capable to compete with an already registered intellectual property develop a prototype of the original. As such, the market can be saturated and the true value of the original intellectual property may decrease.

The potential of intellectual property to impact international financial integration is dependent on the extent to which intellectual property is valuable on the international market. Several measures have been put in place which secures and boost the value of intellectual property. Such factors are elaborated below which fall in line with the regulation of International Chamber of Commerce (2016).

- Financial compensation in case of the violation of property rights.

- Giving up or canceling those product orders that use a trademark without authorization and sanctioning the persons in question according to the legislation at national or international level depending on the typology of the trademark. 
- Confiscation of the intellectual property right of the persons who produce products that violate its basic rights and principles.

In these circumstances it can be appreciated that the protection of intellectual property rights is extremely important and its purpose is to protect the product of human intelligence and whilst guaranteeing consumers that they can use those products and services since they are compliant and registered according to the legislation Dam (1987).

Most often, the value of an intellectual property appreciates with time. When the value of the intellectual property meets the needs of the international market, the probability is high that it can foster financial integration. This explains the purpose of this research to clarify the effects of intellectual property on international financial integration. The section 3. describes the data and methodology, section 4. describes the model and the findings, section 5. explains the conclusion and ends with a reference section.

\section{Data and Methodology}

The data used in this research was ascertained from World Development Indicators of the World Bank database and International Financial Statistics of the International Monetary Fund database. The data is an annual data which spans from the years 2000-2018. The span of the data facilitates the analysis of the dependent and independent variables starting from the dot com era. The data ends in 2018 because most of the variables do not have data for the years 2019 and 2020. The data is ascertained for 29 countries; 28 countries which form the European Union (EU) and Moldova. Moldova is added to the sample size due to the keen relationship they have with Romania (economically, culturally and language); their geographical location is ideal to include them in the analysis to find out the role they play and can play. Also, the data is a panel data. The United Kingdom is included in the EU countries since they happen to be part of the EU as at 31st December, 2019. The variables used in this research includes international financial integration (dependent variable), intellectual property (independent variable); net assets, GDP per capita, population, exchange rate regime (control variables). These are key variables that most researchers have assessed to conclude as key determinants for international financial integration. Table 1. describes the variables into details. 
Table 1. Detail measures of variables

\begin{tabular}{|c|c|c|}
\hline NOTATION & VARIABLE NAME & COMPUTATION \\
\hline ifi & $\begin{array}{l}\text { International } \\
\text { financial integration }\end{array}$ & $\begin{array}{l}\text { The level of financial integration measured by } \\
\text { net foreign assets per gross domestic product. }\end{array}$ \\
\hline ifieq & $\begin{array}{l}\text { International } \\
\text { financial integration }\end{array}$ & $\begin{array}{l}\text { The level of financial integration measured by } \\
\text { dividing the total of net portfolio equity and net } \\
\text { foreign direct investment by GDP. }\end{array}$ \\
\hline ip & Intellectual property & $\begin{array}{l}\text { Summation of the total number of patent } \\
\text { applications, trademarks and interior design. }\end{array}$ \\
\hline pat & Patent applications & $\begin{array}{l}\text { The number of patent applications through the } \\
\text { approved institutional bodies. }\end{array}$ \\
\hline indtot & Industrial design & Total number of industrial design application \\
\hline trdmrk & $\begin{array}{l}\text { Trademarks } \\
\text { applications }\end{array}$ & $\begin{array}{l}\text { The number of trademark applications through } \\
\text { the approved institutional bodies. }\end{array}$ \\
\hline netcap & Net capital & $\begin{array}{l}\text { Net capital account (balance of payment) } \\
\text { expressed in current US dollars. }\end{array}$ \\
\hline gdpcap & $\begin{array}{l}\text { Gross domestic } \\
\text { product per capita }\end{array}$ & $\begin{array}{l}\text { Gross domestic product divided by midyear } \\
\text { population. }\end{array}$ \\
\hline pop & Total population & Total number of people living in a country. \\
\hline err & Exchange rate regime & $\begin{array}{l}\text { Exchange rate arrangement (classified into } \\
\text { dummy variables } 1 \text { to } 3 \text { ). }\end{array}$ \\
\hline
\end{tabular}

Source: own computations based on the specialized literature

\subsection{Methodology}

The main objective of this research is to find the extent to which intellectual property influences international financial integration. Also, the extent to which intellectual property and international financial integration correlate is also analyzed. The main hypotheses for this research are stated below.

In Table 1. All the data is obtained from World Development Indicators of the World Bank database except for exchange rate arrangement which was obtained from International Financial Statistics of the International Monetary Fund database.

${ }^{*}$ Table 2. describes further the exchange rate arrangement 
- H1: There is a positive relationship between intellectual property and international financial integration.

- H2: There is a correlation between intellectual property influences international financial integration.

Table 2. Exchange rate arrangement classification*

\begin{tabular}{|c|l|}
\hline CODES & DESCRIPTION \\
\hline 1 & Currency bond \\
\hline 1 & Currency board arrangement \\
\hline 1 & Exchange arrangement with no separate legal tender \\
\hline 1 & No separate legal tender \\
\hline 2 & Conventional peg \\
\hline 2 & Conventional pegged arrangement \\
\hline 2 & Crawling band \\
\hline 2 & Crawling peg \\
\hline 2 & Craw-like arrangement \\
\hline 2 & Pegged exchange rate within horizontal bands \\
\hline 2 & Stabilized arrangement \\
\hline 3 & Floating \\
\hline 3 & Free floating \\
\hline 3 & Independently floating \\
\hline 3 & Managed floating with no pre-determined path for the exchange rate \\
\hline 3 & Other managed floating \\
\hline
\end{tabular}

Source: IMF classification before 1998

Fixed effects and ordinary least square (OLS) models are used in the regression. The fixed effects model follows the approach of Gangl (2010) where this model is ideal for causal inference. Also, several researchers such as

\footnotetext{
* The codes 1, 2 and 3 denotes fixed, intermediate and floating exchange rate regimes respectively.
} 
Aghion et al (2004), Hinz and Gartner (2005) and (Arránz Becker et al., 2013) have used this model in their research. The modelled equation is stated below.

$$
\begin{aligned}
& \delta_{i, t}=\alpha+\beta_{1}\left(i p_{i t}\right)+\beta_{2}\left(v \chi_{i t}\right)+\theta_{i, t}+\varepsilon_{i, t} \\
& \delta_{i, t}=\alpha+\beta_{1}\left(p a t_{i t} * t r d m r k_{i t} * i n d_{i t}\right)+\beta_{2}\left(v \chi_{i t}\right)+\theta_{i, t}+\varepsilon_{i, t} \\
& \text { where; } \\
& i=\text { country } \\
& t=\text { year } \\
& \delta=\text { international financial integration } \\
& p a t=\text { patents } \\
& \text { trdmrk= trademarks } \\
& \text { ind }=\text { industrial designs } \\
& v \chi=\text { vector of control variables } \\
& \theta=\text { the fixed year-effect/ fixed country-effect } \\
& \varepsilon=\text { the residual term of the regression }
\end{aligned}
$$

The equation (1) is a model with intellectual property (independent variable) which consists of the aggregate of total number of patents, total number of trademarks and total number of industrial design variables. The equation (2) is a model which considers total number of patents, total number of trademarks and total number of industrial designs (independent variables) whilst finding the interaction that exists among them. The vector of control variables includes variables such as net assets, GDP per capita, population and exchange rate regime.

\section{The Model and Findings}

Volume-based indicators are used as a measure of international financial integration in this paper; two indicators are used. First, international financial integration is measured by dividing net foreign assets of a country by its gross domestic product. This is used to determine the financial flows of a country in relation to other countries. Below is the equation. 


$$
I F I_{i, t}=\frac{N F A_{i, t}}{G D P_{i, t}}
$$

Secondly, international financial integration is assessed by dividing net portfolio equity and net foreign direct investment by gross domestic product. This approach is used to determine the total fooreign capital holding of a county in comparison to other countries. Mathematically, the equation is written as:

$$
\operatorname{IFIE} Q_{i, t}=\frac{N P E Q_{i, t}+N F D I_{i, t}}{G D P_{i, t}}
$$

The below table shows the summary statistics of the variables where log is applied on each variable with the exception of exchange rate regime which is a dummy variable. The data summary statistics depicts that the observations for net assets per GDP as a measure of international financial integration is almost twice that of portfolio equity and foreign direct investment per GDP. This means the results for net assets per GDP as a measure of international financial integration is accurate than the other.

\begin{tabular}{|c|c|c|c|c|c|}
\hline Variable & Mean & Min & Max & Std. Dev. & Obs \\
\hline ifi & 2.93 & -2.82 & 6.69 & 1.32 & 411 \\
\hline ifieq & -3.32 & -7.47 & 2.19 & 1.83 & 227 \\
\hline ip & 9.25 & 2.48 & 12.42 & 1.52 & 544 \\
\hline tmtot & 9.27 & 6.40 & 11.63 & 1.08 & 502 \\
\hline ptot & 6.84 & 1.10 & 11.13 & 1.93 & 509 \\
\hline indtot & 7.32 & 0.69 & 11.38 & 1.87 & 311 \\
\hline netcap & 19.92 & 11.98 & 23.31 & 1.94 & 384 \\
\hline gdpcap & 9.92 & 6.09 & 11.69 & 0.92 & 551 \\
\hline pop & 15.84 & 12.87 & 18.23 & 1.38 & 551 \\
\hline trade & 0.03 & -0.79 & 1.41 & 0.47 & 551 \\
\hline err123 & 2.44 & 1 & 3 & 0.82 & 551 \\
\hline
\end{tabular}

Table 3. Summary statistics of the variables

Source: own computations based on the data provided by World Bank and International Monetary Fund 
Also, among the variables for intellectual property, trademarks exhibit the lowest standard deviation with a value of 1.08. Although the data for trademarks does not differ much, the value each trademark carries is essential to the development of an economy.

Table 4. Shows the correlation among the variables. The correlation that exists between international financial integration and intellectual property shows positive. Nevertheless, the extent to which these variables (intellectual property, patent, trademarks and industrial design) correlate falls below average.

\section{Table 4. Correlation matrix}

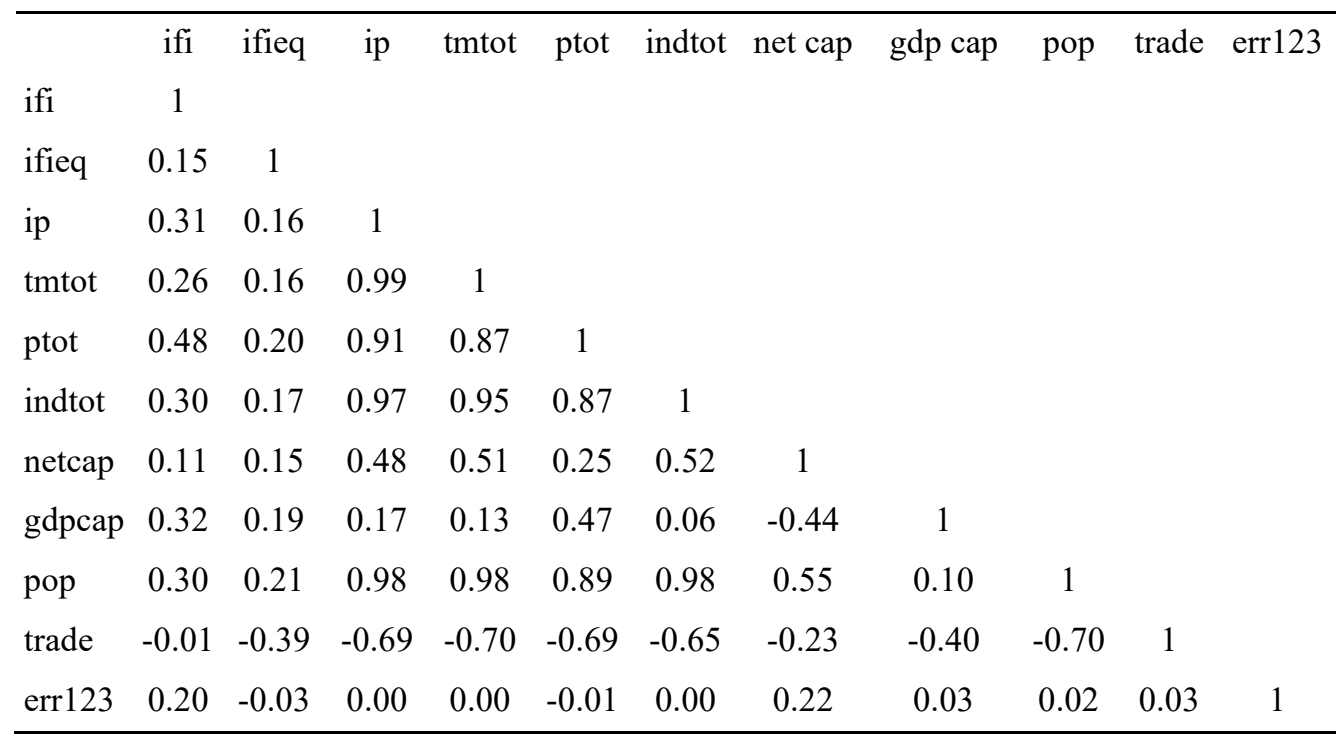

Source: own computations based on the data provided by World Bank and International Monetary Fund

Only patent has a correlation value of 0.48 which appears to be average. Hence, the relationship between international financial integration and intellectual property is not strong enough.

\subsection{Findings}

Prior to the analysis, log is applied for the variables with the exception of exchange rate arrangements. Then, Hausman test is used to detect whether fixed-effects model or random effects model suits the regression. 
Table 5. Results for IFI regression (fixed-effect model)

\begin{tabular}{|c|c|c|c|c|}
\hline VARIABLES & (1) & (2) & (3) & (4) \\
\hline \multirow[t]{2}{*}{ ip } & $-0.157 *$ & -0.060 & & \\
\hline & $(0.088)$ & $(0.064)$ & & \\
\hline \multirow[t]{2}{*}{ tmtot } & & & -2.011 & -3.149 \\
\hline & & & $(2.822)$ & $(3.569)$ \\
\hline \multirow[t]{2}{*}{ ptot } & & & 2.129 & -1.117 \\
\hline & & & $(3.261)$ & (3.699) \\
\hline \multirow[t]{2}{*}{ tmtot\#ptot } & & & -0.157 & 0.166 \\
\hline & & & $(0.408)$ & $(0.495)$ \\
\hline \multirow[t]{2}{*}{ indtot } & & & -2.286 & $-5.879 *$ \\
\hline & & & $(2.701)$ & $(3.316)$ \\
\hline \multirow{2}{*}{ tmtot\#indtot } & & & 0.353 & 0.699 \\
\hline & & & $(0.397)$ & $(0.476)$ \\
\hline \multirow[t]{2}{*}{ ptot\#indtot } & & & -0.087 & 0.626 \\
\hline & & & $(0.531)$ & $(0.592)$ \\
\hline \multirow[t]{2}{*}{ tmtot\#ptot\#indtot } & & & -0.003 & -0.071 \\
\hline & & & $(0.062)$ & $(0.073)$ \\
\hline \multirow[t]{2}{*}{ netcap } & -0.074 & -0.063 & -0.009 & 0.070 \\
\hline & $(0.057)$ & $(0.050)$ & $(0.064)$ & $(0.048)$ \\
\hline \multirow[t]{2}{*}{ gdpcap } & 0.082 & $-0.718^{*}$ & 0.249 & $-2.151 *$ \\
\hline & $(0.300)$ & $(0.419)$ & $(0.478)$ & $(1.074)$ \\
\hline \multirow[t]{2}{*}{ pop } & -4.085 & $-7.255 * * *$ & -6.487 & $-16.379 * *$ \\
\hline & $(2.440)$ & $(1.744)$ & $(5.380)$ & $(6.613)$ \\
\hline \multirow[t]{2}{*}{ trade } & 0.588 & $-1.426^{*}$ & 0.777 & -2.763 \\
\hline & $(0.642)$ & $(0.699)$ & $(0.865)$ & $(1.608)$ \\
\hline \multirow[t]{2}{*}{ err2 } & 0.333 & -0.056 & 0.703 & 0.046 \\
\hline & $(0.213)$ & $(0.306)$ & $(0.435)$ & $(0.365)$ \\
\hline \multirow[t]{2}{*}{ err3 } & 0.269 & 0.076 & 0.420 & -0.122 \\
\hline & $(0.184)$ & $(0.266)$ & $(0.336)$ & $(0.341)$ \\
\hline \multirow[t]{2}{*}{ Constant } & 69.162* & $125.053 * * *$ & 115.119 & $301.824 * *$ \\
\hline & $(39.680)$ & (28.163) & (93.903) & (119.221) \\
\hline Country effect & Yes & No & Yes & No \\
\hline Year effect & No & Yes & No & Yes \\
\hline Observations & 265 & 265 & 169 & 169 \\
\hline R-squared & 0.065 & 0.240 & 0.167 & 0.415 \\
\hline Number of countries & 26 & 26 & 20 & 20 \\
\hline
\end{tabular}

Note: $* * *, * *$ and $*$ represents statistical significance level at $1 \%, 5 \%$ and $10 \%$ respectively. Source: own computations based on WB and IMF data 
The results of the Hausman test shows that fixed effect is applicable since the chi-squared values are 0.007 and 0.0001 for ifi and ifieq respectively. In using fixed effects, both year and country effects are considered. The option robust is used in the regression. For robustness check, ordinary least square model is used. The results obtained for this regression is shown in Table 5.

In Table 5., intellectual property is significant at $10 \%$ significance level in the case where country effects is considered. The effect of intellectual property on international financial integration is negative. Where year effect is applied, intellectual property is not significant but depicts a negative effect of international financial integration. In regression (3) and (4) where the interactions among trademarks, patents and industrial design is considered, the independent variables are not significant.

In Table 6. the regressions (1) and (2), intellectual property is not significantly affecting international financial integration. Nevertheless, intellectual property shows a negative trend.

In regression (3) and (4), trademarks and patents show positive impact on international financial integration at $1 \%$ significance level for patents both cases where country and year effects are applied. Trademarks is significant at $5 \%$ and $10 \%$ where country and year effects are applied respectively. However, the interaction between trademarks and patents is negative at $1 \%$ significance level in both cases where country and year effects are applied.

Industrial design only exhibits a positive impact at 5\% significance level when year effect is applied. The interaction of trademarks and patents, each with industrial design shows a negative impact though they are significant except when year effect is applied on trademarks and industrial design. Finally, the interaction among trademarks, patents and industrial design are significantly positive on international financial integration at 5\% and $10 \%$ respectively where country and year effects are applied respectively.

For robustness check, the ordinary least square model is used. Logarithm to the base 10 is applied to the variables prior to the regression. Also, both country-effect and year-effect are used in the regressions. 
Table 6. Results for IFIEQ regression (fixed-effect model)

\begin{tabular}{|c|c|c|c|c|}
\hline VARIABLES & (1) & (2) & (3) & (4) \\
\hline \multirow[t]{2}{*}{ ip } & -0.128 & -0.108 & & \\
\hline & $(0.142)$ & $(0.150)$ & & \\
\hline \multirow[t]{2}{*}{ tmtot } & & & $10.948 * *$ & $11.488 * * *$ \\
\hline & & & $(3.843)$ & $(3.372)$ \\
\hline \multirow[t]{2}{*}{ ptot } & & & $24.192 * * *$ & $36.432 * * *$ \\
\hline & & & $(5.654)$ & $(9.411)$ \\
\hline \multirow[t]{2}{*}{ tmtot\#ptot } & & & $-2.749 * * *$ & $-3.683 * * *$ \\
\hline & & & $(0.644)$ & $(0.804)$ \\
\hline \multirow[t]{2}{*}{ indtot } & & & 2.885 & $18.036 * *$ \\
\hline & & & $(6.046)$ & $(8.153)$ \\
\hline \multirow[t]{2}{*}{ tmtot\#indtot } & & & -0.622 & $-1.803 * *$ \\
\hline & & & $(0.655)$ & $(0.625)$ \\
\hline \multirow[t]{2}{*}{ ptot\#indtot } & & & $-2.028 *$ & $-4.907 * *$ \\
\hline & & & $(0.988)$ & $(1.801)$ \\
\hline \multirow[t]{2}{*}{ tmtot\#ptot\#indtot } & & & $0.242 * *$ & $0.490 * * *$ \\
\hline & & & $(0.106)$ & $(0.153)$ \\
\hline \multirow[t]{2}{*}{ netcap } & 0.121 & 0.113 & 0.108 & 0.018 \\
\hline & $(0.132)$ & $(0.155)$ & $(0.148)$ & $(0.135)$ \\
\hline \multirow[t]{2}{*}{ gdpcap } & -0.362 & -0.746 & 1.274 & 3.392 \\
\hline & $(0.670)$ & $(1.271)$ & $(2.216)$ & (4.774) \\
\hline \multirow[t]{2}{*}{ pop } & 0.643 & 0.342 & 6.018 & 43.971* \\
\hline & $(3.866)$ & $(2.596)$ & $(5.651)$ & $(22.401)$ \\
\hline \multirow[t]{2}{*}{ trade } & 2.287 & -0.073 & 0.565 & 5.478 \\
\hline & $(1.386)$ & $(2.228)$ & (1.124) & $(5.868)$ \\
\hline \multirow[t]{2}{*}{ err2 } & $0.935 * * *$ & $-1.274^{*}$ & $1.356 * * *$ & 0.691 \\
\hline & $(0.307)$ & $(0.675)$ & $(0.336)$ & $(0.648)$ \\
\hline \multirow[t]{2}{*}{ err3 } & $-0.514 *$ & $-1.283 * * *$ & 0.044 & 1.269 \\
\hline & $(0.291)$ & $(0.280)$ & $(0.485)$ & $(0.802)$ \\
\hline \multirow[t]{2}{*}{ Constant } & -10.949 & -1.986 & -204.051 & $-884.804 *$ \\
\hline & $(60.786)$ & $(40.908)$ & $(127.287)$ & $(416.945)$ \\
\hline Country effect & Yes & No & Yes & No \\
\hline Year effect & No & Yes & No & Yes \\
\hline Observations & 136 & 136 & 75 & 75 \\
\hline R-squared & 0.079 & 0.314 & 0.447 & 0.685 \\
\hline No. of countries & 23 & 23 & 16 & 16 \\
\hline
\end{tabular}

Note: $* * *, * *$ and $*$ represents statistical significance level at $1 \%, 5 \%$ and $10 \%$ respectively. Also, standard errors are in parentheses.

Source: own computations based on World Bank and IMF data 
The regressions run using the OLS model uses the same variables as used to run the fixed-effect panel estimation. This will help to make comparative analyses of the results. Table 7 shows the results for if $i$ as the dependent variable whilst

Table 7. Results for IFI regression (OLS model)

\begin{tabular}{|c|c|c|c|c|}
\hline VARIABLES & (1) & (2) & (3) & (4) \\
\hline \multirow[t]{2}{*}{ LOGip } & -0.157 & 0.080 & & \\
\hline & $(0.123)$ & $(0.111)$ & & \\
\hline \multirow[t]{2}{*}{ LOGtmtot } & & & -2.011 & -2.467 \\
\hline & & & $(2.993)$ & $(1.493)$ \\
\hline \multirow[t]{2}{*}{ LOGptot } & & & 2.129 & $-3.823 * *$ \\
\hline & & & $(2.335)$ & $(1.928)$ \\
\hline \multirow[t]{2}{*}{ c.LOGtmtot\#c.LOGptot } & & & -0.157 & $0.437 *$ \\
\hline & & & $(0.327)$ & $(0.222)$ \\
\hline \multirow[t]{2}{*}{ LOGindtot } & & & -2.286 & $-3.541 * * *$ \\
\hline & & & $(2.779)$ & $(1.116)$ \\
\hline \multirow[t]{2}{*}{ c.LOGtmtot\#c.LOGindtot } & & & 0.353 & $0.360 * *$ \\
\hline & & & $(0.410)$ & $(0.160)$ \\
\hline \multirow[t]{2}{*}{ c.LOGptot\#c.LOGindtot } & & & -0.087 & $0.597 * * *$ \\
\hline & & & $(0.423)$ & $(0.205)$ \\
\hline \multirow[t]{2}{*}{$\begin{array}{l}\text { c.LOGtmtot\#c.LOGptot\#c.LOGindt } \\
\text { ot }\end{array}$} & & & -0.003 & $-0.059 * * *$ \\
\hline & & & $(0.052)$ & $(0.019)$ \\
\hline \multirow[t]{2}{*}{ LOGnetcap } & -0.074 & $-0.217 * * *$ & -0.009 & $-0.175 * *$ \\
\hline & $(0.058)$ & $(0.054)$ & $(0.061)$ & $(0.083)$ \\
\hline \multirow[t]{2}{*}{ LOGgdpcap } & 0.082 & $0.152 * *$ & 0.249 & $-0.289 *$ \\
\hline & $(0.183)$ & $(0.077)$ & $(0.312)$ & $(0.151)$ \\
\hline \multirow[t]{2}{*}{ LOGpop } & $-4.085 * *$ & 0.089 & $-6.487 *$ & -0.376 \\
\hline & $(1.637)$ & $(0.128)$ & $(3.769)$ & $(0.384)$ \\
\hline \multirow[t]{2}{*}{ LOGtrade } & 0.588 & $1.033 * * *$ & 0.777 & 0.474 \\
\hline & $(0.419)$ & $(0.219)$ & $(0.762)$ & $(0.324)$ \\
\hline \multirow[t]{2}{*}{ err2 } & 0.333 & $-0.496 * *$ & $0.703 *$ & $-0.789 * *$ \\
\hline & $(0.219)$ & $(0.228)$ & $(0.384)$ & $(0.313)$ \\
\hline \multirow[t]{2}{*}{ err3 } & $0.269 *$ & -0.276 & 0.420 & $-0.807 * * *$ \\
\hline & $(0.157)$ & $(0.202)$ & $(0.274)$ & $(0.267)$ \\
\hline \multirow[t]{2}{*}{ Constant } & $70.942 * * *$ & $2.741 * *$ & 117.106 & $33.847 * * *$ \\
\hline & $(26.950)$ & $(1.291)$ & $(71.20)$ & $(9.748)$ \\
\hline Country effect & Yes & No & Yes & No \\
\hline
\end{tabular}




\begin{tabular}{|l|c|c|c|c|c|}
\hline Year effect & No & Yes & & No & Yes \\
\hline R-squared & 0.692 & 0.261 & & 0.641 & 0.366 \\
\hline Observations & 265 & 265 & & 169 & 169 \\
\hline
\end{tabular}

Note: ${ }^{* * *},{ }^{* *}$ and $*$ represents statistical significance level at $1 \%, 5 \%$ and $10 \%$ respectively. Also, standard errors are in parentheses.

Source: own computations based on the data provided by World Bank and International Monetary Fund

Table 8 shows the results for ifieq as the dependent variable.

Table 8. Results for IFIEQ regression (OLS model)

\begin{tabular}{|c|c|c|c|c|}
\hline VARIABLES & $(1)$ & $(2)$ & (3) & (4) \\
\hline \multirow[t]{2}{*}{ LOGip } & -0.128 & -0.089 & & \\
\hline & $(0.180)$ & $(0.153)$ & & \\
\hline \multirow[t]{2}{*}{ LOGtmtot } & & & $10.948 * *$ & -0.005 \\
\hline & & & $(5.145)$ & $(2.823)$ \\
\hline \multirow[t]{2}{*}{ LOGptot } & & & $24.192 * * *$ & 3.702 \\
\hline & & & $(5.979)$ & $(4.629)$ \\
\hline \multirow[t]{2}{*}{ c.LOGtmtot\#c.LOGptot } & & & $-2.749 * * *$ & -0.324 \\
\hline & & & $(0.692)$ & $(0.490)$ \\
\hline \multirow[t]{2}{*}{ LOGindtot } & & & 2.885 & 2.724 \\
\hline & & & $(6.420)$ & $(3.651)$ \\
\hline \multirow[t]{2}{*}{ c.LOGtmtot\#c.LOGindtot } & & & -0.622 & -0.205 \\
\hline & & & $(0.733)$ & $(0.333)$ \\
\hline \multirow[t]{2}{*}{ c.LOGptot\#c.LOGindtot } & & & $-2.028 * *$ & -0.637 \\
\hline & & & $(0.884)$ & $(0.591)$ \\
\hline \multirow[t]{2}{*}{ c.LOGtmtot\#c.LOGptot\#c.LOGindtot } & & & $0.242^{* *}$ & 0.051 \\
\hline & & & $(0.095)$ & $(0.057)$ \\
\hline \multirow[t]{2}{*}{ LOGnetcap } & 0.121 & 0.098 & 0.108 & 0.077 \\
\hline & $(0.154)$ & $(0.117)$ & $(0.212)$ & $(0.240)$ \\
\hline \multirow[t]{2}{*}{ LOGgdpcap } & -0.362 & $1.763 * * *$ & 1.274 & 1.375 \\
\hline & $(0.721)$ & $(0.438)$ & $(1.835)$ & $(0.992)$ \\
\hline \multirow[t]{2}{*}{ LOGpop } & 0.643 & -0.240 & 6.018 & $2.072 * * *$ \\
\hline & $(2.994)$ & $(0.243)$ & $(6.045)$ & $(0.704)$ \\
\hline \multirow[t]{2}{*}{ LOGtrade } & $2.287^{*}$ & $0.950 * *$ & 0.565 & 0.105 \\
\hline & $(1.286)$ & $(0.435)$ & $(1.627)$ & $(0.776)$ \\
\hline \multirow[t]{2}{*}{ err2 } & $0.935^{* * * *}$ & $-1.697 * *$ & $1.356 * * *$ & $-1.554 * *$ \\
\hline & $(0.348)$ & $(0.737)$ & $(0.492)$ & $(0.764)$ \\
\hline err3 & -0.514 & -0.460 & 0.044 & $-1.315^{* *}$ \\
\hline
\end{tabular}




\begin{tabular}{|l|c|c|c|c|}
\hline & $(0.357)$ & $(0.595)$ & $(0.611)$ & $(0.572)$ \\
\hline Constant & & - & & \\
\hline & -10.489 & $16.663 * * *$ & $-197.361 *$ & $-52.741 * *$ \\
\hline Country effect & $(46.140)$ & $(5.302)$ & $(117.483)$ & $(24.475)$ \\
\hline Year effect & Yes & No & Yes & No \\
\hline R-squared & No & Yes & No & Yes \\
\hline Observations & 0.655 & 0.461 & 0.621 & 0.621 \\
\hline
\end{tabular}

Note: $* * *, * *$ and $*$ represents statistical significance level at $1 \%, 5 \%$ and $10 \%$ respectively. Also, standard errors are in parentheses.

Source: own computations based on the data provided by World Bank and International Monetary Fund

In the following part, how intellectual property has evolved in the member countries of the European Union in the last two decades is analyzed, taking into account all the processes that influence it and the elements that compose it.

Considering the Figure 1., the table shows the aggregate value of intellectual property from the year 2000 to 2018. Intellectual property is substantially high in Germany than the other countries. This is followed by France, Spain, the United Kingdom and Italy. Intellectual property is seen to be high in developed countries, followed by the emerging economies and the developing countries. Moldova exhibits an interesting characteristic. The aggregate value is marginal in comparison to over EU countries such as Cyprus, Estonia, Ireland, Lithuania, Luxembourg, Latvia, Malta, Netherlands and Slovenia. This shows the capability of Moldova to perform better than other EU countries in the near future.

If Moldova has built its intellectual property capacity to this height, then Moldova can perform better than other countries when it joins the EU. This is one of the strong holds of the county which they can capitalize on to fast forward the growth of the country. Although the records of intellectual property counts substantially but its impact is determined mainly by the impact it has on the resident country and also on the global market. Moreover, in order to see the separate evolution of the elements that compose the intellectual property (trademarks, industrial design, patent) we will present in the following the differences that these elements register in the EU member countries. 


\section{Figure 1. Evolution of intellectual property in EU in the priod 2000 to} 2018

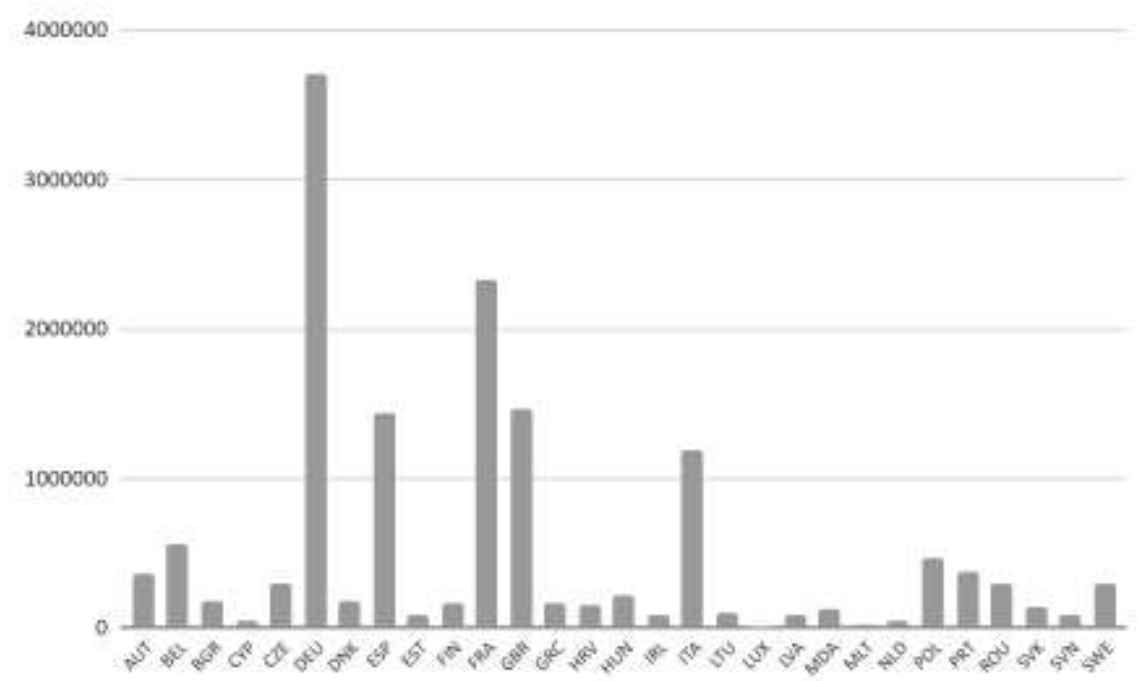

Source: own computations based on the data provided by World Bank and International Monetary Fund

As shown in figure 2, developed countries also exhibit high records of trademarks than the emerging and developing countries. Among the variables which is accumulated to ascertain intellectual property, trademarks have the highest records. This depicts that in most countries, trademarks form a great part of their intellectual property than industrial design or parents.

This can be attributed to the nature of trademarks and role it plays globally. Developed countries still exhibit higher records than the emerging economies and the developing countries. Moldova hereby exhibits a lower record which is similar to several EU countries. Although, the records for patent are generally lower than trademarks and industrial design, one record of patent is prone to have a higher impact on a country and in the international market when compare to trademarks and industrial design. 
Figure 2. Values of trademarks for the countries from the year 2000 to 2018

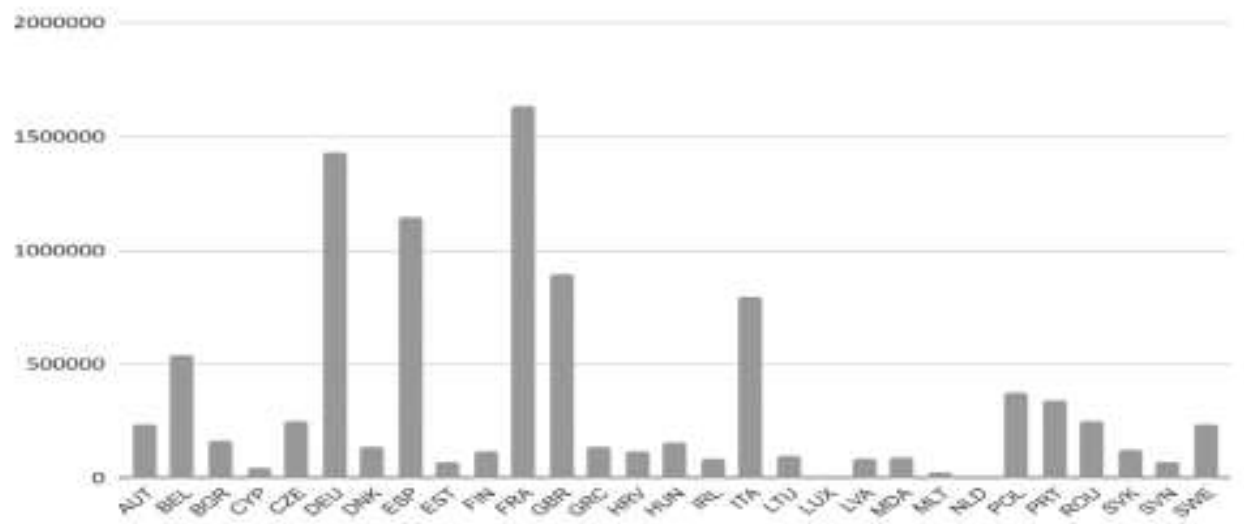

Source: own computations based on the data provided by World Bank and International Monetary Fund

\section{Conclusions}

Intellectual property remains a key element and its protection will trigger innovation to the apex. Nevertheless, the direction of innovation can foster financial integration or cause financial disintegration. Thus, when the innovated products and services can serve other countries aside from the country of origin, then financial integration can be fostered. Alternatively, if the innovated products and services are unable to serve foreign market, then financial disintegration may occur or may not be fostered. Aside, there are also several factors that can contribute to the extent to which intellectual property affects financial integration. They include quality, cost of production, transportation, among others.

This research is centered on finding the effect of intellectual property on international financial integration. Also, the relationship between international financial integration and intellectual property is analyzed.

Upon a careful analysis, we draw several conclusions which are elaborated below. Firstly, the results show that intellectual property has a positive relationship with international financial integration. Nevertheless, the extent to which they correlate is below average. This depicts that when 
intellectual property is carefully considered by firms and governmental institutions, it can be a major source of revenue for the $s$ to stakeholders and the economy at large. Also, the benefits can be reaped by other economies while the origin gains the upper hand of advancing their economy.

Finally, the results show that intellectual property has a transitory effect on international financial integration. This is influenced by the extent to which an intellectual property is relevant in a country and/or in the global market. The core reason behind this outcome can be based on the purpose and potential that lies in the intellectual properties. If the purpose of an intellectual property does not aim to serve the interest of the global economy, international financial integration can be hindered. Also, when an intellectual property lacks the potential to be robust in the global economy, international financial integration will be hindered.

Following the analysis, we can see that there are two types of differences in terms of results. The first difference refers to the type of method used. In the first situation, using the fixed effects method we can see that there is a correlation between financial integration and intellectual property, and in the second situation, using the OLS method we have no changes or a correlation between the two elements.

The second difference refers to the results of the first method used (fixed effects) and we can see that in the first type of regression, there is no positive relationship between intellectual property and financial integration, in which case, the second hypothesis was tested and which relates that there is a correlation between the two elements. Therefore, the second regression was achieved in which financial integration is expressed this time by dividing the total net investment portfolio and net foreign direct investment by gross domestic product. In this case, the results show that there is both a positive link between certain elements of intellectual property taken in correlation with the financial integration process, and a negative link as observed in the situation mentioned above.

Further research can be conducted considering other variables and methodology. Also, in-depth analysis can be made to ascertain the effects of subgroups. 


\section{References}

Aghion, P., Bond, S., Klemm, A. and Marinescu, I., 2004. Technology and financial structure: are innovative firms different? Journal of the European Economic Association, 2(2-3), pp.277-288.

Arránz Becker, O., Salzburger, V., Lois, N. and Nauck, B. (2013). What narrows the stepgap? Closeness between parents and adult (step)children in Germany. Journal of Marriage and Family, 75(5), 1130-1148.

Dam, K.W., 1987. The Growing Importance of International Protection of Intellectual Property. The International Lawyer, pp.627-638.

Menezes, H. Z., \& de Santana Falcão, D. (2020). Poder y autonomía de las organizaciones internacionales: la OMPI en la gobernanza de los derechos de propiedad intelectual. Estudos Internacionais, 8(1), 7-26. doi:10.5752/P.2317-773X.2020V8N1P7-26

Emhart, A. P. (2019), Las acciones civiles por infracciones al derecho de propiedad intelectual. Revista Chilena De Derecho Y Tecnología, 8(2), p. 38. doi:10.5354/0719-2584.2019.53985

EU (2005), Opinion of the European Economic and Social Committee on the Proposal for a Directive of the European Parliament and of the Council amending Directive 98/71/EC on the legal protection of designs. Official Journal of the European Union, 17 November.

Gancia, G. \& Bonfiglioli, A., 2008. North-South trade and directed technical change. Journal of International Economics, 76(2), pp. 276-295.

Gangl, M. (2010), Causal inference in sociological research. Annual Review of Sociology, 36, 21-47.

Goldstein, P.\& Reese, R. A. (2008), Copyright, Patent, Trademark and Related State Doctrines: Cases and Materials on the Law of Intellectual Property. 6th ed. s.1.: New York: Foundation Press.

González-González, C. S., López, L. F., \& Barreto, D. M. (2017), The intellectual property of content published in virtual campuses: what legal and technological aspects should be considered? RED. Revista de Educación a Distancia(53), 3. doi:10.6018/red/53/5

Hinz, T. and Gartner, H. (2005), Geschlechtsspezifische Lohnunterschiede in Branchen, Berufen und Betrieben. Zeitschrift für Soziologie, 34, 22-39. International Chamber of Commerce (2016), Adjudicating intellectual property disputes, s.l.: s.n. 
Jones, S. \& Smith, R., 1991. Putting trade mark law in touch with commerce. Law Society Guardian Gazette, 88(12).

Lin, T. C. (2013), Executive Trade Secrets. Notre Dame Law Review, 87(3), p. 911.

Mossinghoff, G.J. (1984), The importance of intellectual property protection in international trade. BC Int'l \& Comp.L. Rev., 7, p.235.

Schroeder, D. \& Singer, P. (2009), Prudential Reasons for IPR Reform. s.l.: CAPPE, University of Melbourne.

Trinder, B. (1992), The Blackwell Encyclopedia of Industrial Archaeology. Blackwell Publishers, pp. 207-208.

UK Public General Acts (1988), Copyright, Designs and Patents Act. Retrieved from: https:/www.legislation.gov.uk/ukpga/1988/48/ contents).

WIPO (2016), Understanding Copyright and Related Rights Retrieved from: https://www.wipo.int/edocs/pubdocs/en/wipo_pub_909_2016.pdf).

WIPO (2013), Intellectual Property Handbook: Policy, Law and Use. Chapter 2: Fields of Intellectual Property Protection. Retrieved from: https://web.archive.org/web/20130520221306/http://www.wipo.int/expo $\mathrm{rt} /$ sites/www/about-ip/en/iprm/pdf/ch2.pdf)

WIPO, 2016. Settling Disputes and Enforcing IP Rights. Retrieved from: https://www.wipo.int/sme/en/settle_ip_disputes/). 